\title{
Interaksi Sosial dan Komunikasi Antar Etnik di Tempat Kerja (Studi Kasus interaksi Etnik Tionghoa dan Melayu di PT. Permata Topaz Khatulistiwa Pontianak)
}

\author{
Vivian, Riris Loisa \\ vivianve83@gmail.com, ririsl@fikom.untar.ac.id \\ Fakultas Ilmu Komunikasi Universitas Tarumanagara
}

\begin{abstract}
The purpose of this study was to describe the social interaction that occurred between Chinese and Malay ethnic groups in the working environment of PT. Permata Topaz Khatulistiwa, Pontianak, West Kalimantan. The reseach is based on the theory of social interaction that explains that social interaction is a dynamic social relationship that involves relationships between individuals and groups. This study uses qualitative case study method. Data collected through interview, observation and literature study. The conclusion of this study is that the interaction between ethnic Chinese and ethnic Malays in the work environment takes place in a formal context characterized by mutual mutual respect, and is friendly and support each other when working together. But in communicating between cultures, there are inter-ethnic barriers, namely the constraints of regional languages and language styles that indicated to prejudice.
\end{abstract}

Keywords: Social Interaction, Intercultural Communication, Chinese Ethnicity, Malay Ethnicity, Work Environment

\begin{abstract}
Abstrak
Penelitian ini bertujuan untuk menggambarkan interaksi sosial dan komunikasi antar etnik di tempat kerja pada PT. Permata Topaz Khatulistiwa Pontianak, Kalimantan Barat. Teori yang digunakan dalam penelitian ini, interaksi sosial yang menyatakan bahwa interaksi sosial merupakan hubungan-hubungan sosial yang dinamis menyangkut hubungan antara orangorang perorangan dan kelompok. Penelitian ini menggunakan pendekatan penelitian kualitatif dengan metode studi kasus. Pengumpulan data dilakukan melalui wawancara, observasi dan studi pustaka. Kesimpulan dari penelitian ini adalah bahwa interaksi antar etnis Tionghoa dan etnis Melayu di lingkungan kerja berlangsung dalam konteks formal ditandai saling menghargai, terbuka, dan bersifat kekeluargaan dan saling membantu ketika bekerjasama untuk mengerjakan tugas. Namun dalam berkomunikasi antar budaya, terdapat sedikit hambatan antar etnis, yaitu kendala bahasa daerah dan gaya berbahasa yang berindikasi dapat menimbulkan prasangka.
\end{abstract}

Kata Kunci: Interaksi Sosial, Komunikasi Antarbudaya, Etnis Tionghoa, Etnis Melayu, Lingkungan kerja 


\section{Pendahuluan}

Indonesia adalah negara kepulauan yang memiliki keberagaman. Indonesia merupakan pusat lalu lintas perdagangan dunia karena letak geografis Indonesia yang strategis. Berdasarkan data sensus Badan Pusat Statistik pada tahun 2017 ada 714 suku bangsa dan 1.100 bahasa daerah di Indonesia.

Kota Pontianak merupakan ibukota salah satu provinsi di negara Indonesia yaitu Kalimantan Barat yang penduduknya berjumlah 5,3 juta jiwa pada tahun 2018. Berdasarkan data statistik suku di Kalimantan Barat ada tiga suku utama yakni etnis Melayu 30\% dan etnis Tionghoa 12\%.

Etnis Melayu merupakan kaum yang mendominasi di kota Pontianak. Asal usul kedatangan etnis Melayu ke kota Pontianak cukup sulit diungkap sebab relatif sedikit sumber bukti lisan maupun tulisan. Berdasarkan pandangan Anthropologi mengungkapkan etnis Melayu dapat dilihat melalui ciri-ciri dan karakteristik fisik yang hampir sama yaitu kepala bundar, lengan pendek. Hal tersebut dilandaskan karena etnis Melayu merupakan campuran ras Mongolid dan Australomelanesia (Hasan, 2014:5).

Berbeda halnya dengan etnis Melayu, etnis Tionghoa sebagai kaum minoritas juga tersebar dan menetap di kota Pontianak. Tionghoa adalah kebudayaan Tiongkok yang ada tengah dunia. Orang yang berasal dari Tiongkok atau keturunannya biasanya disebut sebagai orang Tionghoa (Wang, 2013: 189). Etnis Tionghoa sudah berdomisili di beberapa wilayah tersebut dari masa nenek moyang mereka. Hal ini terjadi karena etnis Tionghoa mengalami kelaparan dan mereka bertujuan untuk melakukan perdagangan di Indonesia.

Di dalam kehidupan bermasyarakat manusia dituntut untuk dapat menyelaraskan perannya sebagai makhluk sosial. Manusia dalam menjalankan hidupnya akan membutuhkan satu sama lain. Etnis Melayu dan etnis Tionghoa di kota Pontianak merupakan dua bagian etnis yang memiliki perbedaan dan keberagaman budaya. Hal tersebut merupakan pemicu terjadi komunikasi antar budaya. Komunikasi antarbudaya terjadi bila produsen pesan adalah budaya lain dan penerima pesannya merupakan anggota budaya lain (Sihabudin, 2011:21). Sementara itu, budaya merupakan tatanan pengetahuan, kepercayaan, nilai, sikap, objek-objek materi dan milik yang diperoleh kelompok orang besar dari generasi ke generasi melalui usaha individu dan kelompok (Mulyana dan Rakhmat, 2010:18).

Pada umumnya proses komunikasi antar budaya dilakukan dalam ruang lingkup kehidupan etnis Tionghoa dan etnis Melayu di lingkungan kerja. Mereka membangun hubungan interaksi sosial antar etnis dalam mencapai tujuan bersama. Komunikasi merupakan salah satu proses interaksi sosial. Interaksi sosial merupakan hubungan yang dinamis antara orang-orang perorangan, antara kelompok-kelompok, atau perorangan dengan kelompok (Soekanto, 2012:55)

Meskipun dihadapkan dengan perbedaan budaya dan bahasa namun interaksi sosial tetap dapat terbentuk di dalam satu lingkungan kerja yang menaungi etnis Melayu dan etnis Tionghoa. Melihat kenyataan di atas, penulis tertarik untuk meneliti mengenai interaksi sosial dan komunikasi antarbudaya etnis Melayu dan etnis Tionghoa di tempat kerja PT. Permata Topaz Khatulistiwa Pontianak. Karena penulis ingin mengetahui seluk beluk mereka dalam menjalin interaksi sosial dan komunikasi antarbudaya kedua etnis. 


\section{Metode Penelitian}

Dalam penelitian ini, penulis memilih menggunakan pendekatan kualitatif. Penelitian kualitatif merupakan penelitian yang bertujuan dalam memahami fenomena apa yang dialami oleh subjek penelitian (Moleong, 2008: 6). Penelitian ini menggunakan metode penelitian studi kasus. Studi kasus adalah studi yang mendalam pada satu kelompok atau peristiwa (Bungin, 2011:132).

Metode penelitian studi kasus memungkinkan penulis untuk mencari, mendapatkan dan mengetahui informasi mengenai interaksi sosial dan komunikasi antarbudaya etnis Tionghoa dan etnis Melayu di tempat kerja PT. Permata Topaz Khatulistiwa Pontianak. Dalam memperkuat penelitian ini, penulis menggunakan metode pengumpulan data dengan melakukan wawancara, observasi, dan studi pustaka. Dalam penelitian ini yang menjadi subyek penelitian adalah pegawai etnis Tionghoa dan etnis Melayu di lingkungan kerja PT. Permata Topaz Khatulistiwa Pontianak. Obyek penelitian adalah penelitian adalah interaksi sosial.

\section{Hasil Temuan dan Diskusi}

\section{a. Perbedaan Nilai Budaya Etnis Tionghoa dan Etnis Melayu di PT. Permata Topaz Khatulistiwa Pontianak}

Budaya dan komunikasi sulit dipisahkan karena budaya dipelajari melalui komunikasi dan pada saat yang sama komunikasi merupakan refleksi dari budaya. Dalam melakukan komunikasi antar etnis terdapat nilai-nilai yang masih sangat dipertahankan setiap etnis. Budaya merupakan salah satu teori yang penulis jadikan sebagai acuan saat menanyakan pertanyaan wawancara kepada narasumber. Berlandaskan pada nilai budaya, berikut penulis jabarkan mengenai hasil temuan penulis lapangan.

\section{1) Nilai Budaya Kekompakan}

Berdasarkan hasil penelitian ini, penulis mengumpulkan data yang mengatakan bahwa antar etnis selalu melakukan kegiatan rutin bersama- sama untuk menciptakan hubungan komunikasi yang baik. Karena Budaya dan komunikasi merupakan satu kesatuan yang tidak dapat dipisahkan. Selain itu sikap solidaritas juga ditanamkan dalam lingkungan kerja. Dari data ini terlihat adanya nilai budaya kekompakan yang masih dipertahankan antar etnis. Menurut narasumber 3 nilai budaya yang hingga kini dipertahankan di lingkungan kerja yaitu solidaritas. Solidaritas mengambil peran dalam menyatukan hubungan antar pegawai. Beban pekerjaan akan terasa lebih mudah bila solidaritas dipertahankan.

\section{2) Nilai budaya Kejujuran}

Penulis merangkum bahwa nilai budaya kejujuran masih dipertahankan oleh etnis Melayu. Nilai budaya kejujuran dianggap penting dalam berkomunikasi dengan setiap orang.

Menurut narasumber 1 yang beretnis Melayu, nilai budaya dalam lingkungan kerja yang masih dipertahankan hingga saat ini adalah suatu kejujuran. Karena ia meyakini bahwa kejujuran merupakan hal yang paling penting dalam segala aspek kehidupan. Kejujuran sejak dini lazim ditanamkan dalam setiap keluarga etnis Melayu. Setiap kontribusi yang ia berikan pada saat bekerja dilandaskan dengan kejujuran. 


\section{3) Nilai Budaya Kerja Keras}

Penulis melihat adanya nilai budaya kerja keras yang terdapat dalam diri etnis Tionghoa. Hal ini dikarenakan etnis Tionghoa yang tidak mudah menyerah untuk mengubah kehidupanya menjadi lebih baik dalam bekerja dengan mencari nafkah bagi dirinya sendiri dan bagi keluarganya.Untuk memperjuangkan hidup yang lebih baik etnis Tionghoa melakukan ekspansi besar-besaran ke Indonesia. Salah satunya adalah kota Pontianak. Kedatangan etnis Tionghoa juga diketahui untuk bercocok tanam serta kegiatan penambangan emas besar-besaran. Ikatan kekeluargaan etnis Tionghoa diketahui terikat erat sehingga seiring berjalannya waktu mereka datang dengan jumlah yang semakin banyak karena setiap datang ke Pontianak tidak hanya sendiri namun juga membawa keluarga. Hal ini sangat memperlihatkan kerja keras yang sudah tertanam pada diri etnis Tionghoa.

\section{b. Komunikasi Antarbudaya Etnis Tionghoa dan Etnis Melayu di PT. Permata Topaz Khatulistiwa Pontianak \\ 1) Saling Menghargai Dalam Komunikasi Antar Etnis}

Penulis merangkum bahwa komunikasi antarbudaya yang terjalin dilandasi atas sikap saling menghargai antar etnis. Hal ini terlihat dari narasumber 1 yang sering memberikan sapaan pada saat bertemu dengan etnis Tionghoa serta menjalin hubungan silahturami antara sesama. Hal ini terbukti dari hasil wawancara dengan narasumber 2 yang mengungkapkan bahwa sebagai etnis Melayu komunikasi yang dijalankan oleh Sutanon relatif terjalin baik. Hal tersebut terlihat dari perilaku saling menyapa dan memberikan salam dan bersilahturami kepada pegawai etnis Tionghoa pada saat bertemu selama berada di lingkungan kerja.

\section{2) Komunikasi Antarbudaya Dilandasi Sikap Terbuka}

Penulis menyimpulkan komunikasi antar budaya yang terjalin antar etnis Tionghoa dan Melayu dilandaskan atas sikap keterbukaan sehingga memberikan ruang diantara kedua etnis untuk dapat saling mengenal dan memiliki rasa simpati terhadap sesama. Komunikasi yang terjadi terlihat dari pernyataan 2 narasumber yakni narsumber 1 yang beretnis Melayu dan narasumber 3 yang beretnis Tionghoa. Tri memaparkan bahwa komunikasi antarbudaya tidak hanya ia terapkan di lingkungan kerja namun juga dijalankan di luar lingkungan kerja. Ia kerap menghabiskan waktu bersama rekan pegawai kantornya yang berbeda etnis dengan nongkrong bersama atau hanya sekadar bersilahturami ke rumah masing-masing. Sejalan dengan apa yang dikemukakan oleh narasumber 3 yaitu Susi yang memaparkan bahwa susi menjalankan komunikasi secara terbuka dan menanamkan sikap respect terhadap etnis lain.

\section{c. Komunikasi Antarbudaya Bercirikan Perbedaan Bahasa dan Gaya Komunikasi Yang Menimbulkan Prasangka}

Penulis menyimpulkan bahwa hambatan-hambatan komunikasi antarbudaya terjadi antara kedua etnis tersebut adalah perbedaan bahasa dan gaya berbahasa.. Adanya kendala-kendala tersebut dapat memicu prasangka dan kesalahpahaman yang terjadi antara kedua etnis tersebut.

Setelah melakukan wawancara mengenai komunikasi antarbudaya yang terjalain antar etnis, terdapat hambatan-hambatan dalam komunikasi antar etnis. Narasumber 2 yang beretnis Melayu merasa bahasa menjadi salah satu penghambat ia dalam melakukan komunikasi karena sebagian besar etnis Tionghoa sering berbahasa khek dan Tiocu kepada sesama etnisnya. Hal ini menyebabkan narasumber 2 tidak mengerti 
apa yang dibicarakan. Sedangkan menurut narasumber 4 yang beretnis Tionghoa mengungkapkan hal yang menjadi penghambat dalam melakukan komunikasi adalah dari cara bicara dan gaya bahasa yang berbeda.

\section{d. Interaksi Sosial Etnis Tionghoa dan Etnis Melayu di PT. Permata Topaz Khatulistiwa Pontianak}

1. Hubungan Yang Berbaur Dalam Melakukan interaksi Sosial

Penulis menyimpulkan interaksi sosial antar etnis Tionghoa dan etnis Melayu yang terjalin dapat dilihat dari adanya kerberbauran antar sesama dalam menyelesaikan suatu permasalahan. Hal ini terlihat dari interaksi yang dilakukan narasumber 2 yaitu Sutanon lebih sering berdiskusi mengenai pekerjaan, saling bekerja sama dan membantu. Sejalan dengan narasumber 4 yakni Hariyanto juga melakukan interaksi dengan etnis Melayu di lingkungan kerjanya contohnya seperti berdiskusi tentang pekerjaan di kantor. Hal ini sejalan dengan penelitian terdahulu Linda Sumilat Paembonan yang berjudul Interaksi dalam Proses Belajar Antarbudaya yang mengatakan bahwa peserta training di Jepang memperlihatkan bahwa mereka memiliki kesadaran diri dan budaya untuk berperilaku selayaknya ketika berinteraksi dengan budaya, orang dan lingkungan di negeri tersebut. Mereka segera menyadari budaya setempat, menyesuaikan dengan kebiasaan, adat-istiadat serta aturan dan norma yang berlaku di negara itu demi kelancaran interaksi komunikasi antarbudaya. Hal ini terlihat bahwa adanya proses yang berbaur dalam menyesuaikan diri.

2. Hubungan Interaksi Sosial Yang Dilandasi Keberagaman

Penulis menyimpulkan adanya keberagaman dalam melakukan interaksi sosial antar etnis Tionghoa dan Melayu seperti adanya interaksi sosial secara langsung maupun secara tidak langsung. Seperti yang diungkapkan oleh Narasumber 1 yakni Tri yang beretnis Melayu mengatakan bahwa Tri melakukan interaksi melalui via chatting melalui handphone dan saling berbincang-bincang pada saat di kantor. Sedangkan interaksi yang dijalankan oleh narasumber 3 mengungkapkan cara interaksinya dengan etnis Melayu melalui cara berpartisipasi pada saat acara buka bersama saat bulan puasa.

3. Interaksi Sosial yang Dilandasi Hubungan Kekeluargaan

Penulis menyimpulkan interaksi sosial antar etnis Tionghoa dan etnis Melayu yang terjalin dapat dilihat dari adanya hubungan kekeluargaan antar sesama dimana adanya pertisipasi etnis lain terhadap hari raya suatu etnis tertentu. Hal ini dapat dilihat dari interaksi yang dilakuikan oleh narasumber 3 sangat bersifat kekeluargaan.

\section{E. Lingkungan Kerja Yang Nyaman di PT. Permata Topaz Khatulistiwa Pontianak}

Penulis menyimpulkan bahwa adanya kenyamanan di dalam lingkungan kerja yang dirasakan oleh narasumber 4 dan narasumber 2. Hal ini dikarenakan mereka saling berbaur dan menerima tanggapan pada saat melakukan komunikasi hal ini dapat dilihat dari hasil wawancara narasumber 4 mengatakan bahwa di dalam lingkungan kerjanya tedapat orang-orang yang mau berbaur, baik junior maupun senior. Sementara itu narasumber 2 mengungkapkan hal yang sama bahwa di dalam lingkungan kerja antar etnis selalu melontarkan candaan dan memberi tanggapan terhadap komunikasi yang dilakukan. Penulis menyimpulkan bahwa adanya kenyamanan di dalam lingkungan kerja yang dirasakan oleh narasumber 4 dan narasumber 2. Hal ini dikarenakan mereka saling berbaur dan menerima tanggapan pada saat melakukan komunikasi. 


\section{Simpulan}

Etnis Tionghoa dan etnis Melayu di PT.Permata Topaz Khatulistiwa Pontianak memiliki nilai budaya yang berbeda dan masing-masing masih dipertahankan oleh antar masing-masing kelompok etnis. Walaupun mempunyai nilai budaya yang berbeda, komunikasi antar etnis juga terjalin dengan baik. Etnis Tionghoa dan Etnis Melayu tidak membedakan satu sama lain. Mereka menanamkan sikap saling menghargai dan tolong menolong.

Dari adanya komunikasi antar etnis yang dilakukan, terjalin interaksi sosial antar etnis. Etnis Tionghoa dan etnis Melayu selalu menyapa apabila saling bertemu, saling melakukan komunikasi melalui grup smartphone, jalan-jalan bersama. Selain itu antar etnis juga saling melakukan silahturami, melakukan kegiatan kantor secara bersama, dan saling bekerja sama di dalam mengerjakan tugas dan saling membantu satu sama lain. Hal ini membuat antar pegawai etnis Tionghoa dan etnis Melayu menjalin hubungan pertemanan.

Namun terdapat sedikit hambatan yang terjadi antar etnis yaitu kendala bahasa dan gaya berbahasa yang dapat menimbulkan prasangka. Seperti etnis Tionghoa yang selalu menggunakan bahasa ibu dalam berkomunikasi dengan sesama etnisnya. Hal ini mengakibatkan etnis Melayu tidak mengerti dan menimbulkan adanya prasangka. Sementara itu gaya bahasa etnis Melayu yang sedikit kasar juga dapat membuat etnis Tionghoa tersinggung dan dapat menciptakan adanya prasangka.

\section{Ucapan Terima Kasih}

Penulis mengucapkan terima kasih kepada PT. Permata Topaz Khatulistiwa Pontianak, key informant dan informan yang telah bersedia meluangkan waktunya serta semua pihak yang telah memberikan dukungan dan bantuan kepada penulis selama proses penyusunan jurnal penelitian ini.

\section{Daftar Pustaka}

Bungin, Burhan. (2011). Penelitian Kualitatif: Komunikasi, Ekonomi, Kebijakan Publik, dan Ilmu Sosial Lainnya. Jakarta : Kencana Prenada Media Group.

Moleong, Lexy J. (2008). Metode Penelitian Kualitatif. Edisi Revisi. Bandung : PT. Remaja Rosdakarya

Mulyana, Deddy dan Jalaludin Rakhmat. (2010). Komunikasi Antarbudaya. Bandung: PT Remaja Rosdakarya

Paembonan, Sumilat Linda. (2009). Interaksi dalam Proses Belajar Antarbudaya. 27 (IX). 33-53

Sihabudin, Ahmad. (2011). Komunikasi Antarbudaya: Satu Perspektif Multidimensi. Jakarta: PT. BumiAskara.

Soekanto, Soerjono. (2012). Sosiologi Suatu Pengantar. Jakarta: Rajawali Pers

Wang, Andri. (2013). The Ancient Chinese Wisdom. Jakarta: Gramedia. 